\title{
A coisa julgada na perspectiva constitucional brasileira
}

\author{
Pedro Pierobon Costa do Prado ${ }^{1}$
}

Resumo: Este artigo tem por finalidade perquirir sobre o "status" constitucional da coisa julgada no Brasil, analisando a evolução no tratamento da matéria.

Palavras-chave: Direito processual civil. Coisa julgada. Constituição.

Abstract: This article is intended to assert on the "status" of the constitutional res judicata in Brazil, analyzing developments in the treatment of the matter.

Keywords: Civil procedural law. Claim preclusion. Constitution.

\section{Introdução}

As normas jurídicas não possuem todas a mesma relevância. Algumas veiculam simples regras, ao passo que outras estatuem verdadeiros princípios. Por isso algumas normas constitucionais são mais diretrizes; outras menos. ${ }^{2}$ Os princípios constitucionais são as linhas mestras de todo o ordenamento, apontando os rumos a serem seguidos pela sociedade e obrigatoriamente perseguidos pelo Estado. Expressam a substância última do querer popular, seus objetivos e desígnios, motivo pelo qual não podem ser contrariados; devem ser prestigiados até as últimas consequências. ${ }^{3}$

Como salientado por Eros Roberto Grau, a ideia de direito expressa um processo de contínua evolução. A teoria jurídica se volta

aos princípios jurídicos, salientando a sua importância, seja porque o modo formal de aplicação do direito (direito formal) não satisfaz socialmente, seja porque o direito moderno (direito posto pelo Estado) não viabiliza, por si só, a fluência das relações sociais e o dinamismo da circulação mercantil, carente de formas renovadas de legitimação. E a verificação de que os princípios são norma jurídica, ao lado das regras - o que converte norma jurídica em gênero, do qual são espécies os princípios e as regras

\footnotetext{
${ }^{1}$ Mestre e especialista em direito processual civil pela PUC/SP.

${ }^{2}$ CARRAZZA, Roque Antonio. Curso de direito constitucional tributário. 6. ed. São Paulo: Malheiros, 1994, p. 27.
} 
${ }^{3}$ ATALIBA, Geraldo. República e Constituição. 3. ed. atual. Rosolea Miranda Folgosi. São Paulo: Malheiros, 2011, p. 34-35. 
jurídicas -, abre novas vias de indagação, riquíssimas, para os que se dedicam à teoria do direito. ${ }^{4}$

Como a Constituição é a norma fundamental da qual todas as demais encontram sua validade no sistema jurídico, ${ }^{5}$ é forçoso reconhecer vigência ao princípio da supremacia das normas constitucionais, também denominado princípio da constitucionalidade, que exige "a conformidade de todas as normas e atos administrativos e atos judiciais, às disposições substanciais ou formais da Constituição". 6

Um eventual desajustamento entre a norma inferior e a Constituição (seja ele material ou formal), mediante declaração inconstitucionalidade, acarreta a nulidade da norma inconstitucional. ${ }^{7}$ Por vezes, o desajustamento entre essas normas poderá ser mais sutil, referindo-se a alguma dúvida sobre a adequada interpretação de norma constitucional, seja ele princípio ou regra. Os princípios constitucionais são, na lição de Luís Roberto Barroso, o ponto de partida do intérprete que espelham toda a ideologia da Constituição,

são as normas eleitas pelo constituinte como fundamentos ou qualificações essenciais da ordem jurídica que institui. A atividade de interpretação da Constituição deve começar pela identificação do princípio maior que rege o tema a ser apreciado, descendo do mais genérico ao mais específico, até chegar à formulação da regra concreta que vai reger a espécie. ${ }^{8}$

Nota-se que é destacada a função dos princípios constitucionais no

\footnotetext{
${ }^{4}$ GRAU, Eros Roberto. O direito posto e o direito pressuposto. 7. ed. São Paulo: Malheiros, 2008, p. 109-110.

5 "Mas a criação da Constituição realiza-se por aplicação da norma fundamental. Por aplicação da Constituição, opera-se a criação das normas jurídicas gerais através da legislação e do costume; e, em aplicação destas normas gerais, realiza-se a criação das normas individuais através das decisões judiciais e das resoluções administrativas. Somente a execução do ato coercivo estatuído por estas normas individuais - o último ato do processo de produção jurídica - se opera em aplicação das normas individuais que a determinam sem que seja, ela própria, criação de uma norma. A aplicação do Direito é, por conseguinte, criação de uma norma inferior com base numa norma superior ou execução do ato coercivo estatuído por uma norma" (KELSEN, Hans. Teoria pura do direito. 6. ed. trad. João Baptista Machado. São Paulo: Martins Fontes, 2003, p. 261).

${ }^{6} \mathrm{RÁO}$, Vicente. $O$ direito e a vida dos direitos. 3. ed. atual. Ovídio Rocha Barros Sandoval. São Paulo: RT, 1991, v. 1, p. 267.

${ }^{7}$ BUZAID, Alfredo. Da ação direta de inconstitucionalidade no direito brasileiro. São Paulo: Saraiva, 1958, p. 43.

${ }^{8}$ BARROSO, Luís Roberto. Interpretação e aplicação da Constituição: fundamentos de uma
}

http://revistasapereaude.org/index.php/edicoes/ano-5-volume-4-novembro-2016 
dogmática constitucional transformadora. São Paulo: Saraiva, 1996, p. 141.

http://revistasapereaude.org/index.php/edicoes/ano-5-volume-4-novembro-2016 
ordenamento jurídico, pois são verdadeiros guias para a correta interpretação das demais normas jurídicas. Entre eles, deve ser realçada a importância do princípio da segurança jurídica, tendente ao alcance de uma desejada estabilidade social, que se desdobra em dois elementos intimamente associados, quais sejam, a segurança jurídica e a proteção da confiança. O primeiro está ligado a uma ideia objetiva, conectada com elementos objetivos da ordem jurídica, v.g., a garantia de estabilidade jurídica, segurança de orientação e realização do direito; o segundo se prende a componentes subjetivos da segurança, v.g., a calculabilidade e previsibilidade dos indivíduos em relação aos efeitos jurídicos dos atos dos poderes públicos. ${ }^{9}$

\section{A segurança jurídica}

A segurança jurídica chega a ser idealizada como a primazia objetiva do Direito, que não obriga só por conseguir se impor eficazmente no meio social. Mais que isso, obriga quando, conseguindo se impor eficazmente, o faz para garantir a segurança e a ordem. O fundamento da obrigatoriedade do direito positivo reside na segurança que apenas ele pode estabelecer entre as diferentes concepções jurídicas em confronto. Se a justiça é encarada como a segunda grande preocupação da ciência jurídica, a primeira é justamente a segurança, a paz e a ordem social. ${ }^{10}$

De modo geral, abrange os seguintes aspectos: a) instituições estatais dotadas de poder e garantias, bem como sujeitas ao princípio da legalidade; b) a confiança nos atos do Poder Público, que deverão ser regidos pela boa-fé e pela razoabilidade; c) a estabilidade das relações jurídicas, manifestada na durabilidade das normas, na anterioridade das leis em relação a fatos sobre os quais incidem e na conservação de direitos em face da lei nova; c) a previsibilidade dos comportamentos (a serem seguidos e suportados); d) a igualdade na lei e perante a lei, inclusive com soluções isonômicas para situações idênticas ou próximas. ${ }^{11}$

Desse modo, a ordem jurídica tem por missão e responsabilidade

\footnotetext{
${ }^{9}$ DIMOULIS, Dimitri; Martins, Leonardo. Teoria geral dos direitos fundamentais. São Paulo: RT, 2007, p. 116-31.

${ }^{10}$ RADBRUCH, Gustav. Filosofia do Direito. 6. ed. Coimbra: Ed. Coimbra, 1997, p. 180.

${ }^{11}$ Nesse sentido: BARROSO, Luís Roberto. Em algum lugar do passado: segurança jurídica,
}

http://revistasapereaude.org/index.php/edicoes/ano-5-volume-4-novembro-2016 
direito intertemporal e o novo Código Civil. Revista de direito RENOVAR, v. 21, 2005.

http://revistasapereaude.org/index.php/edicoes/ano-5-volume-4-novembro-2016 
definir situações e gerar clima de confiança e tranquilidade das pessoas e grupos quanto a seus direitos, deveres e obrigações, seja para exercê-los e cumpri-los adequadamente, seja para poderem prever consequências do descumprimento próprio ou alheio. Tal é o valor da segurança jurídica, indispensável ao convívio social harmonioso e civilizado. ${ }^{12}$

$\mathrm{Na}$ ótica estritamente constitucional, suprindo as lacunas das Constituições de 1824 e 1891, que apenas vedavam a prescrição e a aplicação de leis retroativas (art. 179, II e III, e art. 11, respectivamente), a Constituição de 1934 foi a primeira a tratar expressamente do tema em seu artigo 113, n 03 : “A lei não prejudicará o direito adquirido, o ato jurídico perfeito e a coisa julgada".

A Carta Constitucional de 1937, outorgada em pleno Estado Novo, suprimiu a proteção dada à coisa julgada, assim como vários outros direitos e garantias fundamentais. À propósito, diversas leis com caráter retroativo foram editadas nesta época, v.g., o Decreto-lei $\mathrm{n}^{\circ}$ 58/1937, o Decreto $\mathrm{n}^{\circ} 1.027 / 1939$, o Decreto-Lei $\mathrm{n}^{\circ}$ $5.384 / 1943$, inaugurando um período de acentuada desordem jurídica que transcendia os direitos materiais, chegando a atingir os processos em andamento, como dispunha o Decreto-lei $\mathrm{n}^{\mathrm{o}}$ 4.529/1942, que dispunha sobre a prescrição para a anulação de casamento. $^{13}$

A Constituição de 1946, de cunho democrático, resgatou a proteção da coisa julgada no art. 141, de redação idêntica à Constituição de 1934 neste particular.

Com a instauração do regime militar no país, a Carta de 1967, no seu art. 149, inciso IX, retirou a expressão "a lei não prejudicará”, tradicionalmente presente nos dispositivos constitucionais, para dispor que era assegurado o "respeito ao direito adquirido, ao ato jurídico perfeito e à coisa julgada". A Emenda Constitucional $n^{\circ} 1$, de 17/10/1969, que entrou em vigor após o recrudescimento do regime de exceção, adotou,

${ }^{12}$ DINAMARCO, Cândido Rangel. Fundamentos do processo civil moderno. 6. ed. São Paulo: Malheiros, 2010, v. 1, p. 237.

${ }^{13}$ RODRIGUES JÚNIOR, Otávio Luiz. Coisa julgada e Constituição: os efeitos da lei nova, da mudança de interpretação dos tribunais e das emendas constitucionais sobre a coisa julgada.

http://revistasapereaude.org/index.php/edicoes/ano-5-volume-4-novembro-2016 
Revista do Curso de Mestrado de Direito da UFC, Fortaleza, v. 16/18, n. 4/6, p. 87, jan./dez. 1997-1999, p. 90. 
no art. $153, \S 3^{\circ}$, redação idêntica às Constituições de 1934 e 1946.

\section{Segurança jurídica e coisa julgada na Constituição de 1988}

A Constituição de 1988 (CF/1988), no rol dos direitos e garantias fundamentais, conferindo estabilidade às relações jurídicas consolidadas, estatui no art. $5^{\circ}$, inciso XXXVI, que:

Art. $5^{\circ}$. Todos são iguais perante a lei, sem distinção de qualquer natureza, garantindo-se aos brasileiros e aos estrangeiros residentes no país, a inviolabilidade do direito à vida, à liberdade, à igualdade, à segurança, à propriedade, nos seguintes termos:

XXXVI - a lei não prejudicará o direito adquirido, o ato jurídico perfeito e a coisa julgada.

A atual Constituição reproduz norma tradicional do direito brasileiro, presente desde 1934, com exceção à Carta de 1937. A tutela constitucional recai sobre a coisa julgada material, pois objetiva conferir estabilidade jurídica à prestação jurisdicional definitivamente outorgada às partes. ${ }^{14} \mathrm{~A}$ formal se beneficia apenas indiretamente da proteção, visto que é pressuposto daquela. ${ }^{15}$

A "res iudicata" confere imutabilidade à sentença e a seus efeitos, destinada a conferir estabilidade às relações jurídicas intersubjetivas e segurança ao direito objetivo. ${ }^{16}$ Não se trata de um

instituto confinado ao direito processual. Ela tem, acima de tudo, o significado político-institucional de assegurar a firmeza das situações jurídicas, tanto que erigida em garantia constitucional. Uma vez consumada, reputa-se consolidada no presente e para o

\footnotetext{
${ }^{14}$ Somente as sentenças de mérito são acobertadas pela autoridade da coisa julgada; as de extinção sem resolução do mérito são atingidas apenas pela preclusão - coisa julgada formal (NERY JUNIOR, Nelson. Princípios do processo civil na Constituição Federal. 10. ed. São Paulo: RT, 2010, P. 52). Em sentido contrário: a proteção constitucional é mais abrangente e se estende à coisa julgada formal (MIRANDA, Pontes de. Comentários à Constituição de 1967. São Paulo: RT, 1968, p. 95).

${ }^{15}$ SILVA, José Afonso da. Curso de direito constitucional positivo. 29. ed. São Paulo: Malheiros, 2007, p. 436.

${ }^{16}$ GRINOVER, Ada Pellegrini. O processo: estudos e pareceres. 2. ed. São Paulo: DPJ Editora,
}

http://revistasapereaude.org/index.php/edicoes/ano-5-volume-4-novembro-2016 
2009, p. 65. 
futuro a situação jurídico-material das partes, relativa ao objeto do julgamento e às razões que uma delas tivesse para sustentar ou pretender alguma outra situação. Toda possível dúvida está definitivamente dissipada, quanto ao modo como aqueles sujeitos se relacionam juridicamente na vida comum, ou quanto à pertinência de bens a um deles. As normas e técnicas do processo limitam-se a reger os modelos como a coisa julgada se produz e os instrumentos pelos quais é protegida a estabilidade dessas relações - mas a função dessas normas e técnicas não vai além disso. Nesse sentido é que prestigioso doutrinador afirmou ser a coisa julgada material o direito do vencedor a obter dos órgãos jurisdicionais a observância do que tiver sido julgado (Hellwig). ${ }^{17}$

A segurança, insculpida como valor e direito no preâmbulo e no art. $5^{\circ}$, “caput”, da Constituição, não contempla unicamente a proteção da vida, da incolumidade física ou do patrimônio, mas também e principalmente a própria segurança jurídica, consistente em um mínimo de previsibilidade que o Estado deve oferecer a qualquer cidadão, vinculado à criação de relações jurídicas válidas e eficazes. Ao exercer a função jurisdicional, o Estado revela e impõe às partes a norma a ser respeitada, não lhe sendo lícito desfazê-la em prejuízo das relações jurídicas já constituídas. Por isso, a proteção da coisa julgada é a materialização, sob a forma de uma regra explícita,

do princípio da segurança jurídica, em cujo âmbito se resguardam a estabilidade das relações jurídicas, a previsibilidade das condutas e a certeza jurídica que se estabelece acerca de situações anteriormente controvertidas. De fato, o fim da situaçãolitigiosa e o restabelecimento da paz social são valores relevantes para a sociedade e para o Estado, e em seu nome se impede a reabertura da discussão, mesmo diante da alegada injustiça da decisão. Daí por que, no Brasil, a coisa julgada, de longa data, deixou de ser apenas um instituto de direito processual para adquirir status constitucional. $^{18}$

Necessária a perquirição sobre o patamar constitucional do instituto, isto é, se direito fundamental ou garantia de direitos fundamentais. Conforme lição de Leonardo Greco, com a qual se concorda, a coisa julgada é

a coisa julgada é uma importante garantia fundamental e, como

${ }^{17}$ DINAMARCO, Cândido Rangel. Nova era do processo civil. 4. ed. São Paulo: Malheiros, 2013, p. 222.

${ }^{18}$ BARROSO, Luís Roberto. O controle de constitucionalidade no direito brasileiro:

http://revistasapereaude.org/index.php/edicoes/ano-5-volume-4-novembro-2016 
exposição sistemática da doutrina e análise crítica da jurisprudência. São Paulo: Saraiva, 2004, p. 171-173. 
tal, um verdadeiro direito fundamental, como instrumento indispensável à eficácia concreta do direito à segurança, inscrito como valor e como direito no preâmbulo e no "caput" do artigo $5^{\circ}$ da Constituição de 1988. A segurança não é apenas a proteção da vida, da incolumidade física ou do patrimônio, mas também e principalmente a segurança jurídica. ${ }^{19}$

Tem a coisa julgada, pois, natureza instrumental, representando verdadeira garantia essencial do direito fundamental à segurança jurídica.

Sergio Ribeiro Porto anota que o texto constitucional tem por finalidade oferecer estabilidade às relações jurídico-sociais a partir de determinado ponto, colocando um basta ao conflito para gerar um acertamento definitivo das relações jurídicas. O instituto da coisa julgada possui assento constitucional e seu eventual desrespeito representa verdadeira afronta a uma garantia constitucional. Por isso, é passível de impugnação tal qual a desconsideração de qualquer das garantias fundamentais asseguradas pela Constituição Federal, quer expressas, quer implícitas. Além de estabelecer verdadeira blindagem da decisão jurisdicional contra alterações legislativas futuras, esta impossibilidade também se impõe às próprias decisões jurisdicionais ou atos do Executivo. Portanto, a autoridade da coisa julgada

não pode ser interpretada de forma restritiva, resultando imune apenas contra atos futuros do Poder Legislativo, vez que seu propósito é outorgar estabilidade às relações jurídicas e (indagase!) de que valeria ser a relação jurídica estável apenas contra a lei, não o sendo contra atos do Poder Executivo ou do próprio Poder Judiciário? ${ }^{20}$

Não se pode ter dúvidas sobre o amplo espectro de atuação e incidência do instituto, que imuniza a relação jurídica já consolidada por decisão judicial transitada em julgado contra qualquer alteração futura, seja ela proveniente quer de lei nova, quer de outra decisão judicial ou administrativa. Nessa linha, Araken de Assis assevera que, à margem de quaisquer considerações acerca

do desenvolvimento histórico do direito intertemporal, e do

${ }^{19}$ LEONARDO GRECO. Eficácia da Declaração ‘Erga Omnes' de Constitucionalidade ou Inconstitucionalidade em Relação à Coisa Julgada Anterior. In: "Relativização da Coisa Julgada",

http://revistasapereaude.org/index.php/edicoes/ano-5-volume-4-novembro-2016 
p. 251, 2. ed. 2008. Salvador: JusPODIVM.

${ }^{20}$ PORTO, Sérgio Gilberto. Coisa julgada civil. 3. ed. São Paulo: RT, 2006, p. 59-60. 
seu regime concreto entre nós, três aspectos se evidenciam no inciso sob foco. Em primeiro lugar, a proibição se dirige ao legislador, ante a explícita menção inicial à figura da "lei", notório e conspícuo produto do processo legislativo, nele apontada como o potencial valor deliqüescente. Ademais, o bem jurídico tutelado consiste na segurança jurídica: na ausência desse veto, o legislador assumiria funções onipotentes, quiçá sucumbindo à influência de fatores conjunturais para subtrair dos particulares seus direitos, inclusive aqueles reconhecidos por pronunciamento judiciário. $\mathrm{E}$, finalmente, incumbe à lei infraconstitucional definir objeto da garantia. ${ }^{21}$

Luiz Guilherme Marinoni reforça que a coisa julgada é inerente ao Estado Constitucional, não só assegurada de forma expressa pela Constituição, mas como consequente lógico e necessário do Estado de Direito, encontrando sua base nos princípios da segurança jurídica e da proteção da confiança. No plano objetivo, a segurança jurídica recai sobre a ordem jurídica objetivamente considerada, preocupada com a irretroatividade e a previsibilidade dos atos estatais (art. $5^{\circ}, \mathrm{XXXVI,} \mathrm{da} \mathrm{CF/88).}{ }^{22}$ Em uma perspectiva subjetiva, é vista a partir do ângulo dos cidadãos em face dos atos do Poder Público, aqui surgindo o princípio da proteção da confiança pelos atos oriundos do Estado; uma vez produzida a coisa julgada material, o ato judicial de solução do litígio merece plena confiança, não podendo ser alterado. Em resumo, a coisa julgada serve à realização do princípio da segurança jurídica, já que sem ela não há ordem jurídica e possibilidade de o cidadão confiar nas decisões do Judiciário, inviabilizando-se o Estado de Direito. ${ }^{23}$

Além disso, é contrário à interpretação restritiva do art. $5^{\circ}, \mathrm{XXXVI,} \mathrm{da}$ Constituição. A circunstância de a norma ter se referido ao legislador obviamente não significa dizer que pretendeu liberar o administrador e o juiz para a desrespeitarem. A coisa julgada

expressa a necessidade de estabilidade das decisões judiciais, vistas como atos de positivação do poder, motivo

\footnotetext{
${ }^{21}$ ASSIS, Araken de. Eficácia da coisa julgada inconstitucional. Revista Jurídica, n. 301, nov. 2002, p. 9.

${ }^{22}$ E também: GRECO FILHO, Vicente. Direito processual civil brasileiro. 19. ed. São Paulo: Saraiva, 2008, v. 2, p. 276.
}

http://revistasapereaude.org/index.php/edicoes/ano-5-volume-4-novembro-2016 
${ }^{23}$ MARINONI, Luiz Guilherme. Coisa julgada inconstitucional. 2. ed. São Paulo: RT, 2010, p. 65-68. 
pelo qual, se há sentido em garantir a sua imodificabilidade diante do Legislativo, é mais evidente ainda a imprescindibilidade de se tutelar a sua irretroatividade em relação ao Judiciário. Se a decisão judicial, embora inviolável pelo Legislativo, pudesse ser livremente negada exatamente por aquele que a produziu, não existiria a segurança jurídica indispensável ao Estado de Direito.

$\mathrm{O}$ art. $5^{\circ}, \mathrm{XXXVI}$, quando disse que "a lei não prejudicará a coisa julgada", não quis dizer apenas que a lei não pode modificar a situação definida pela decisão que proferiu coisa julgada, mas sim que nenhuma lei infraconstitucional pode negar ou desproteger a coisa julgada. Qualquer lei que diga que uma decisão, proferida em processo em que todos os argumentos e provas puderam ser apresentados, pode ser revista pelo Poder Judiciário, não acatada pelo Poder Executivo, ou alterada ou modificada pelo Poder Legislativo, é uma lei inconstitucional. ${ }^{24}$

Desse modo, ainda que na fórmula constitucional da coisa julgada esteja dito apenas que "a lei não prejudicará", é notório que

o constituinte minus dixit quam volet, tendo essa garantia uma amplitude mais ampla do que as palavras poderiam fazer pensar. Por força da coisa julgada, não só o legislador carece de poderes para dar nova disciplina a uma situação concreta já definitivamente regrada em sentença irrecorrível, como também os juízes são proibidos de exercer a jurisdição outra vez sobre o caso e as partes não dispõem do direito de ação ou de defesa como meios de voltar a veicular em juízo a matéria já decidida. ${ }^{25}$

Maria Helena Diniz, sobre o tema, ensina que a "res judicata" é um princípio jurídico-positivo que demonstra

o fato de ser a decisão final uma norma individual, cuja validade não poderá ser abolida por uma norma derrogante nem por outra sentença judicial [...], podendo ser apenas desconstituída mediante ação rescisória interposta dentro do biênio decadencial, desde que configurada uma das causas legais arroladas taxativamente no Código de Processo Civil. [...].

\footnotetext{
${ }^{24}$ MARINONI, Luiz Guilherme. Coisa julgada inconstitucional. 2. ed. São Paulo: RT, 2010, p. 69.

${ }^{25}$ DINAMARCO, Cândido Rangel. Nova era do processo civil. 4. ed. São Paulo: Malheiros,
} 
2013, p. 241-242. 
A lei superveniente não poderá alcançar a coisa julgada, nem o órgão judicante poderá decidir novamenteo que estiver decidido como forma imutável de sentença, a fim de que se resguarde a segurança das relações jurídicas. A auctoritas rei judicatae justifica-se no atendimento ao interesse público de estabilidade jurídico-social, cedendo somente ao ataque de decisões anuláveis. Se se admitisse que lei nova viesse a atingir o caso julgado, ter-se-ia anarquia, a lesão de direitos e o descrédito da justiça. ${ }^{26}$

Eduardo Talamini reforça o caráter amplo desse direito ao rechaçar solução interpretativa que o restrinja a um mecanismo meramente instrumental de irretroatividade das leis, devendo-se aplicar a máxima de hermenêutica pela qual as normas sobre direitos e garantias fundamentais merecem interpretação extensiva. Basta comparar a disposição com outras contidas no próprio art. $5^{\circ}$ da Constituição: o inciso XXXV prevê apenas que a "lei não excluirá" o acesso à justiça (mas ninguém duvida que o direito ali consagrado vai muito além disso, impondo a qualquer aplicador do direito o respeito a todas as derivações da inafastabilidade da tutela jurisdicional); o "caput" do art. $5^{\circ}$ refere-se apenas à igualdade "perante a lei", porém se reconhece facilmente a incidência do princípio da isonomia em todo e qualquer momento de aplicação do direito. Tal como sucede nesses casos, a coisa julgada não é mencionada como simples limite, baliza, unicamente da atividade legislativa, pois a sua referência no texto da Constituição implica outras tantas consequências. ${ }^{27}$

A afirmação de que não é dado à lei alguma suprimir a coisa julgada implica também reconhecer que o aplicador da lei não pode, ele mesmo, desrespeitar a coisa julgada. Com efeito, não faria sentido limitar a atividade do "legislador para o fim de proteger a coisa julgada e, ao mesmo tempo, deixar o aplicador da lei livre para agir como bem entendesse. Trata-se de conjugar o art. $5^{\circ}$, XXXVI, com o princípio constitucional da legalidade (art. $5^{\circ}$, II)". Dessa maneira, ficaria definitivamenteafastada a ideia de que o dispositivo estudado trata unicamente de irretroatividade das leis. ${ }^{28}$ Por oportuno mencionar, Robert Alexy, calcado na doutrina e jurisprudência alemãs, reafirma

\footnotetext{
${ }^{26}$ DINIZ, Maria Helena. Lei de introdução às normas do direito brasileiro interpretada. 18. ed. São Paulo: Saraiva, 2013, p. 218.

${ }^{27}$ TALAMINI, Eduardo. Coisa julgada e sua revisão. São Paulo: Revista dos Tribunais, 2005, p. $50-1$.
} 
${ }^{28}$ TALAMINI, Eduardo. Coisa julgada e sua revisão. São Paulo: Revista dos Tribunais, 2005, p. 52-53. 
que "nenhum tribunal pode tomar por base para a sua decisão uma regra que "nem sequer o legislador poderia ordenar". ${ }^{29}$

Nelson Nery Junior explica que a segurança jurídica, trazida pela coisa julgada material, é manifestação e elemento de existência do Estado Democrático de Direito (art. $1^{\circ}$, "caput", da $\mathrm{CF} / 88$ ). O constituinte originário, entre o justo absoluto, utópico, e o justo possível, realizável, seguindo a maioria dos sistemas democráticos ocidentais, optou pelo segundo, o justo possível, consubstanciado na segurança jurídica da coisa julgada material. ${ }^{30}$ Descumprir-se a coisa julgada material é negar o próprio Estado Democrático de Direito, fundamento da república brasileira. ${ }^{31}$

A coisa julgada, continua o autor, "não pode ser modificada nem por emenda constitucional (CF $1 .^{\circ}$ caput e 60 § $4 .^{\circ}$ I e IV), nem pela lei (CF 5. ${ }^{\circ} \mathrm{XXXVI).} \mathrm{A}$ fortiori, não poderia ser modificada por outra decisão do Poder Judiciário", salvo nas hipóteses excepcionais que autorizam a propositura da ação rescisória em face da extrema gravidade de que pode se revestir a sentença. ${ }^{32}$

Teresa Arruda Alvim Wambier e JoséMiguel Garcia Medina elucidam que a interpretação da Constituição Federal, por si só, dispensaria menção expressa à proteção da coisa julgada, por se tratar de ideia correlata ao Estado Democrático de Direito (art. $1^{\circ}$, da CF/1988), que impõe a existência de instituto cabaz de atribuir estabilidade e indiscutibilidade às decisões judiciais. ${ }^{33}$

\footnotetext{
${ }^{29}$ ALEXY, Robert. Direito constitucional e direito ordinário. Jursidição constitucional e jurisdição especializada. Trad. L. A. Heck. São Paulo: RT, 2003, p. 57.

30 "O fundamento político da coisa julgada descansa na necessidade de paz social e segurança jurídica. O Estado tem interesse em que se faça Justiça e, por isso, confere aos litigantes uma gama de recursos, por meio dos quais se procura o aprimoramento da decisão. Há um momento em que urge uma definição, pondo fim ao litígio. Para tanto, a lei, a partir do trânsito em julgado, confere à decisão caráter de imutabilidade" (FERNANDES, Sérgio Ricardo de Arruda. Alguns aspectos da coisa julgada material no direito processual civil brasileiro. RePro 62. São Paulo: RT, abr/jun. 1991, p. 71.

${ }^{31}$ NERY JUNIOR, Nelson. Princípios do processo na Constituição Federal. 10. ed. São Paulo: RT, 2010, p. 68.

${ }^{32}$ NERY JUNIOR, Nelson. Princípios do processo na Constituição Federal. 10. ed. São Paulo: RT, 2010, p. 51-52.

33 "É irrelevante a menção expressa, na Constituição Federal, acerca da coisa julgada - muito embora a Constituição Federal brasileira o faça, no art. $5^{\circ}$, inc. XXXVI, no sentido de não se permitir à lei retroagir para atingir a coisa julgada - porquanto esta é umbilicalmente ligada ao
}

http://revistasapereaude.org/index.php/edicoes/ano-5-volume-4-novembro-2016 
Estado Democrático de Direito (WAMBIER, Teresa Alvim Arruda Alvim; MEDINA, José 
De outro lado, há quem veja o instituto fora do direito constitucional, pois a Constituição do Brasil de 1988, ao contrário da portuguesa, não se preocupou em dispensar tratamento à coisa julgada em si. Apenas proclamou a sua imunidade em relação aos efeitos da lei nova, instituindo regra de direito intertemporal. ${ }^{34}$ A preocupação do legislador constituinte

foi apenas a de pôr a coisa julgada a salvo dos efeitos de lei nova que contemplasse regra diversa de normatização da relação jurídica objeto de decisão judicial não mais sujeita a recurso, como uma garantia dos jurisdicionados. Trata-se, pois, de tema de direito intertemporal em que se consagra o princípio da irretroatividade da lei nova. ${ }^{35}$

O dispositivo se dirigiria unicamente ao legislador ordinário, norma de sobre-direito destinada a disciplinar a edição de outras normas jurídicas pelo legislador: proíbe-se ao Poder Legislativo "prejudicar" a coisa julgada via edição de leis e tudo o mais no instituto seria matéria da legislação ordinária. ${ }^{36}$ Daí que

a noção de intangibilidade da coisa julgada, no sistema jurídico brasileiro, não tem sede constitucional, mas resulta,

Miguel Garcia. O dogma da coisa julgada. São Paulo: RT, 2003, p. 22). Neste mesmo sentido: BUENO, Cassio Scarpinella. "Coisa julgada inconstitucional": uma homenagem a Araken de Assis. In: ALVIM, Arruda; ALVIM, Eduardo Arruda; BRUSCHI, Gilberto Gomes; CHECHI, Mara Larsen; COUTO, Mônica Boneti. Execução civil e temas afins - do CPC/1973 ao Novo CPC: estudos em homenagem ao professor Araken de Assis. São Paulo: RT, 2014, p. 145.

${ }^{34}$ NASCIMENTO, Carlos Valder do; PEREIRA JÚNIOR, Lourival. Natureza da coisa julgada: uma abordagem filosófica. In: NASCIMENTO, Carlos Valder do; DELGADO, José Augusto (Coord). Coisa julgada inconstitucional. 2. ed. Belo Horizonte: Fórum, 2008, p. 105-145. THEODORO JÚNIOR, Humberto; FARIA, Juliana Cordeiro de. Reflexões sobre o princípio da intangibilidade da coisa julgada e sua relativização. In: NASCIMENTO, Carlos Valder do; DELGADO, José Augusto (Coord). Coisa julgada inconstitucional. 2. ed. Belo Horizonte: Fórum, 2008, p. 161-200.

${ }^{35}$ THEODORO JÚNIOR, Humberto; FARIA, Juliana Cordeiro de. Reflexões sobre a coisa julgada inconstitucional e os instrumentos processuais para seu controle. In: NASCIMENTO, Carlos Valder do; THEODORO JÚNIOR, Humberto; FARIA, Juliana Cordeiro de. Coisa julgada inconstitucional: a questão da segurança jurídica. Belo Horizonte: Fórum, 2011, p. 172-173.

${ }^{36}$ Segundo Paulo Roberto de Oliveira Lima, a regra constitucional se dirige ao legislador ordinário, é verdadeira norma de sobre-direito que "disciplina a própria edição de outras regras jurídicas pelo legislador, ou seja, ao legislar é interdito ao Poder legiferante 'prejudicar' a coisa julgada. É esta a única regra sobre 'coisa julgada' que adquiriu foro constitucional. Tudo o mais no instituto é matéria objeto de legislação ordinária. Para ele, mais adiante, "a proteção constitucional da coisa julgada não é mais do que uma das muitas faces do princípio da

http://revistasapereaude.org/index.php/edicoes/ano-5-volume-4-novembro-2016 
irretroatividade da lei" (LIMA, Paulo Roberto de Oliveira. Contribuição à teoria da coisa julgada. São Paulo: Editora Revista dos Tribunais, 1997, p. 84-6). 
antes, de norma contida no Código de Processo Civil (art. 457), pelo que de modo algum pode estar imune ao princípio da constitucionalidade, hierarquicamente superior. ${ }^{37}$

\section{Coisa julgada e o Supremo Tribunal Federal}

Importante consignar que o Supremo Tribunal Federal, por reiteradas ocasiões, consagrou a natureza de garantia da norma inserta no art. $5^{\circ}$, inciso XXXVI, da Constituição Federal, acolhendo o entendimento majoritário sobre a matéria. ${ }^{38}$

No plano do direito comparado, a proteção à coisa julgada, mesmo em países onde não seja prevista expressamente no texto constitucional, é encarada como

${ }^{37}$ THEODORO JÚNIOR, Humberto; FARIA, Juliana Cordeiro de. Reflexões sobre a coisa julgada inconstitucional e os instrumentos processuais para seu controle. In: NASCIMENTO, Carlos Valder do; THEODORO JÚNIOR, Humberto; FARIA, Juliana Cordeiro de. Coisa julgada inconstitucional: a questão da segurança jurídica. Belo Horizonte: Fórum, 2011, p. 174-175.

38 Por todos: RECURSO EXTRAORDINÁRIO - COISA JULGADA EM SENTIDO MATERIAL - INDISCUTIBILIDADE, IMUTABILIDADE E COERCIBILIDADE: ATRIBUTOS ESPECIAIS QUE QUALIFICAM OS EFEITOS RESULTANTES DO COMANDO SENTENCIAL - PROTEÇÃO CONSTITUCIONAL QUE AMPARA E PRESERVA A AUTORIDADE DA COISA JULGADA - EXIGÊNCIA DE CERTEZA E DE SEGURANÇA JURÍDICAS - VALORES FUNDAMENTAIS INERENTES AO ESTADO DEMOCRÁTICO DE DIREITO - EFICÁCIA PRECLUSIVA DA "RES JUDICATA" "TANTUM JUDICATUM QUANTUM DISPUTATUM VEL DISPUTARI DEBEBAT" CONSEQUENTE IMPOSSIBILIDADE DE REDISCUSSÃO DE CONTROVÉRSIA JÁ APRECIADA EM DECISÃO TRANSITADA EM JULGADO, AINDA QUE PROFERIDA EM CONFRONTO COM A JURISPRUDÊNCIA PREDOMINANTE NO SUPREMO TRIBUNAL FEDERAL - A QUESTÃO DO ALCANCE DO PARÁGRAFO ÚNICO DO ART. 741 DO CPC - MAGISTÉRIO DA DOUTRINA - RECURSO DE AGRAVO IMPROVIDO. - A sentença de mérito transitada em julgado só pode ser desconstituída mediante ajuizamento de específica ação autônoma de impugnação (ação rescisória) que haja sido proposta na fluência do prazo decadencial previsto em lei, pois, com o exaurimento de referido lapso temporal, estar-se-á diante da coisa soberanamente julgada, insuscetível de ulterior modificação, ainda que o ato sentencial encontre fundamento em legislação que, em momento posterior, tenha sido declarada inconstitucional pelo Supremo Tribunal Federal, quer em sede de controle abstrato, quer no âmbito de fiscalização incidental de constitucionalidade. - A superveniência de decisão do Supremo Tribunal Federal, declaratória de inconstitucionalidade de diploma normativo utilizado como fundamento do título judicial questionado, ainda que impregnada de eficácia "ex tunc" como sucede, ordinariamente, com os julgamentos proferidos em sede de fiscalização concentrada (RTJ 87/758 - RTJ 164/506-509 - RTJ 201/765) -, não se revela apta, só por si, a desconstituir a autoridade da coisa julgada, que traduz, em nosso sistema jurídico, limite insuperável à força retroativa resultante dos pronunciamentos que emanam, "in abstracto", da Suprema Corte. Doutrina. Precedentes. - O significado do instituto da coisa julgada material como expressão da própria supremacia do ordenamento constitucional e como elemento inerente à existência do Estado Democrático de Direito (STF, $2^{\mathrm{a}}$ Turma, Ag-Rg-RE 592.912, rel. Min. Celso de Mello, j.

http://revistasapereaude.org/index.php/edicoes/ano-5-volume-4-novembro-2016

D.O.I: $10.20523 /$ sapereaude-ano5-vol-4pg-123-159 
03/04/2012, p. 22/11/2012).

http://revistasapereaude.org/index.php/edicoes/ano-5-volume-4-novembro-2016 
consequência do direito à tutela jurisdicional efetiva. Entende-se que a resposta do Judiciário, para ser eficaz socialmente, não pode ficar eternamente à mercê de modificações, revisões e reversões. ${ }^{39}$

$\mathrm{Na}$ Espanha, a intangibilidade da coisa julgada tem lugar como corolário dos princípios da segurança jurídica e da tutela jurisdicional efetiva. ${ }^{40}$ Sob este prisma que o Tribunal Constitucional Espanhol reafirmou a importância da coisajulgada dentre o catálogo dos direitos fundamentais (sentenças STC 119/1988, STC 189/1990, STC 231/1991, STC 142/1992, STC 34/1993, STC 43/1998 e STC 112/1999). ${ }^{41}$

A Constituição de Portugal, no seu art. 29, item 5, prevê que "ninguém poderá ser julgado mais do que uma vez pela prática do mesmo crime”. Apesar de só se fazer referência ao processo criminal, afirma-se que a coisa julgada é decorrência direta do princípio da segurança jurídica, aplicável, pois, a qualquer espécie de processo judicial. ${ }^{42}$ Paulo Otero arrazoa que a

intangibilidade do caso julgado resulta ainda do princípio constitucional do Estado de Direito Democrático (artigo $2^{\circ}$ ), enquanto pressuposto de garantia de valores da segurança e da certeza da ordem jurídica. Admitir a modificabilidade do caso julgado, fosse por via judicial ou legislativa, significaria sempre colocar em causa as idéias de estabilidade, de segurança e mesmo de tutela de confiança dos cidadãos. ${ }^{43}$

De conteúdo próximo, a Constituição da Itália, promulgada em 27 de dezembro de 1947, estatui, em seu art. 25, que "ninguém pode ser punido senão por

39 GRECO, Leonardo. Eficácia da declaração erga omnes de constitucionalidade ou inconstitucionalidade em relação à coisa julgada anterior, In: Relativização da coisa julgada (org. Fredie Didier Jr.). Salvador: Editora Jus Podium, 2004, p. 255.

${ }^{40}$ RINCÓN, Jorge Carreras del. Comentarios a la doctrina procesal civil del tribunal constitucional y del tribunal supremo, Madrid: Marcial Pons, 2002, p. 411; JUNOY, Joan Picó y. Las garantias constitucionales del proceso, Barcelona: J. M. Bosch Editor, 1997, p. 69.

${ }^{41}$ AROCA, Juan Montero e MATÍES, José Flors. Amparo constitucional y proceso civil, Valência: Tirant lo blanch, 2008, p. 86.

${ }^{42}$ MIRANDA, Jorge. Manual de direito constitucional: inconstitucionalidade e garantia da constituição. 2. ed. Coimbra: Coimbra Editora, 2005, t. 6, p. 277. 
${ }^{43}$ OTERO, Paulo. Ensaio sobre o caso julgado inconstitucional. Lisboa: Lex Edições Jurídicas, 1993, p. 50. 
aplicação de uma lei que tenha entrado em vigor antes de cometido o facto. Ninguém pode ser submetido a medidas de segurança, salvo nos casos previstos pela lei".

A Constituição da República Federal da Alemanha, no seu art. 103, item 3, preceitua que "ninguém pode ser punido mais de uma vez pelo mesmo ato com base no direito penal comum". Embora não faça referência expressa à coisa julgada, seu fundamento constitucional está ligado ao princípio do Estado de Direito, o qual tem como componente essencial a garantia da certeza do direito, compreendidos o desenvolvimento regular do processo e a estabilidade de sua conclusão. ${ }^{44}$ Para arrematar, a Corte Europeia de Direitos Humanos reafirmou que a coisa julgada é um elemento indispensável para a concretização do direito à tutela jurisdicional efetiva, conforme decidido nos casos Brumarescu v. Romênia, julgado em 28/10/99; Pullar v. Reino Unido, julgado em 10/06/96; e Antonetto v. Itália, j. em 20/07/2000. Nessa linha, Paolo Biavati e Federico Carpi comentam que "l'avere conferito ai giudici la giurisdizione su determinate materie comporta necessariamente l'attribuzione non solo dell'eficacia obbligatoria, ma anche della stabilità dei contenuti delle relative pronuncie". 45

No Brasil, em que pese o "status" constitucional da coisa julgada, a fixação dos contornos que a moldam e o seu conteúdo são objeto de legislação infraconstitucional, responsável por traçar o perfil dogmático do instituto. Valendo-se de uma ponderação de valores, é possível que não se atribua a certas decisões a aptidão de se tornarem imutáveis e indiscutíveis; em outros casos, pode exigir pressupostos e requisitos menos rigorosos para sua ocorrência. ${ }^{46}$

Não sendo a coisa julgada fenômeno de razão natural, como se verá adiante, é a lei que lhe confere a existência e lhe fixa a eficácia. Sendo assim, a própria lei poderia privá-la de sua força, como acontece em matéria penal. ${ }^{47} \mathrm{Na}$ medida em que a coisa julgada é um dado político, cabe à lei disciplinar o campo "de incidência, as

\footnotetext{
${ }^{44}$ ROSENBERG, Leo; SCHWAB, Karl H.; GOTTWALD, Peter. Zivilprofsrecht. 15. ed. Munique: Beck, 1993, p. 914-915.

${ }^{45}$ BIAVATI, Paolo; CARPI, Federico. Diritto procesuale comunitário. 2. ed. Milano: Giufrè, 2000 , p. 240.

${ }^{46}$ DIDIER JÚNIOR, Fredie; BRAGA, Paula Sarno; OLIVEIRA, Rafael. Curso de direito processual civil. 4. ed. Salvador: Juspodium, 2009, v. 2, p. 408.

${ }^{47}$ COUTURE, Eduardo J. Fundamentos del derecho procesal civil. 3.ed. Buenos Aires: Ediciones
} 
Depalma, 1997, p. 407. 
condições de formação, os limites objetivos e subjetivos, os meios de revisão e todos os demais aspectos do instituto, sendo, portanto, "sempre possível a sua (re)modelação infraconstitucional". ${ }^{48}$

\section{Conclusão}

A linha de raciocínio acima exposada foi acolhida pelo Supremo Tribunal Federal, o qual reconheceu expressamente que o conceito e os limites da coisa julgada são instituídos pela legislação infraconstitucional. ${ }^{49}$ Assim, para a Corte, está sob a proteção constitucional a garantia da intangibilidade da coisa julgada, e não seu conteúdo material. ${ }^{50}$ Desse modo, o instituto da coisa julgada, embora de matriz constitucional, tem sua conformação delineada pela legislação ordinária, que estabelece seus limites (objetivos e subjetivos) e pode indicar as situações nas quais o institutocede em relação a outros valores também protegidos pela Constituição. ${ }^{51}$

${ }^{48}$ TALAMINI, Eduardo. Coisa julgada e sua revisão. São Paulo: RT, 2005, p. 52.

${ }^{49}$ CONSTITUCIONAL. ADMINISTRATIVO. SERVIDOR PÚBLICO DO ESTADO DE MATO GROSSO DO SUL. FORMA DE CÁLCULO DO ADICIONAL POR TEMPO DE SERVIÇO. LEIS ESTADUAIS 1.102/90 E 2.157/2000. Arts. $5^{\circ}$, XXXVI, e 37, XIV, da CF/88. OFENSA INDIRETA. I - A Corte tem se orientado no sentido de que o conceito dos institutos do direito adquirido, do ato jurídico perfeito e da coisa julgada não se encontram na Constituição, mas na legislação ordinária (Lei de Introdução ao Código Civil, art. $6^{\circ}$ ). Assim, está sob a proteção constitucional a garantia desses direitos, e não seu conteúdo material (RE 437.384-AgR/RS, Rel. Min. Carlos Velloso; AI 135.632-AgR/RS, Rel. Min. Celso de Mello). II - A apreciação do recurso extraordinário, no que concerne à alegada ofensa ao art. 37, XIV, da Constituição, encontra óbice na Súmula 279 do STF. III - A ofensa à Constituição, acaso existente, seria reflexa, o que inviabiliza o recurso extraordinário. IV - Agravo regimental improvido. (STF, $1^{\text {a }}$ Turma, AgRg-RE 461.286, rel. Min. Ricardo Lewandowski, j. 20/06/2006, p. 15/09/2006).

${ }^{50}$ AGRAVO DE INSTRUMENTO - MATÉRIA TRABALHISTA - PRESSUPOSTOS DE ADMISSIBILIDADE DA AÇÃO RESCISÓRIA - ALEGAÇÃO DE TRANSGRESSÃO AO POSTULADO DA AUTORIDADE DA COISA JULGADA - INOCORRÊNCIA - AUSÊNCIA DE OFENSA DIRETA À CONSTITUIÇÃO - RECURSO IMPROVIDO. - O debate em torno da aferição dos pressupostos de admissibilidade da ação rescisória não viabiliza o acesso à via recursal extraordinária, por envolver discussão pertinente a tema de caráter eminentemente infraconstitucional. Precedentes. - Se a discussão em torno da integridade da coisa julgada reclamar análise prévia e necessária dos requisitos legais, que, em nosso sistema jurídico, conformam o fenômeno processual da res judicata, revelar-se-á incabível o recurso extraordinário, eis que, em tal hipótese, a indagação em torno do que dispõe o art. $5^{\circ}$, XXXVI, da Constituição por supor o exame, in concreto, dos limites subjetivos (CPC, art. 472) e/ou objetivos (CPC, arts. 468, 469, 470 e 474) da coisa julgada - traduzirá matéria revestida de caráter infraconstitucional, podendo configurar, quando muito, situação de conflito indireto com o texto da Carta Política, circunstância essa que torna inviável o acesso à via recursal extraordinária. Precedentes. (STF, 2 ${ }^{\mathrm{a}}$ Turma, AI 287.964, rel. Min. Celso de Mello, j. 26/11/2002, p. 19/12/2002). ${ }^{51}$ STF, RE 681.953, DJe de 09.11.12, rel. Celso de Mello. É o que justifica a existência da ação rescisória prevista no art. 485 do $\mathrm{CPC} / 73$ (art. 966 do CPC/15), a qual submete a coisa julgada a outros valores

http://revistasapereaude.org/index.php/edicoes/ano-5-volume-4-novembro-2016

D.O.I: $10.20523 /$ sapereaude-ano5-vol-4pg-123-159 
preponderantes, como a imparcialidade do juiz (incisos I e II), a boa-fé e a seriedade 
Em síntese, com as vênias aos entendimentos contrários, o modelo constitucional do processo civil contempla a coisa julgada, ainda que confira ao legislador infraconstitucional certa margem de liberdade para a definição dos atos a serem revestidos por ela. A partir do art. $5^{\circ}$, inciso XXXVI, da Constituição da República, fica vedada a possibilidade de a lei retroagir em prejuízo da coisa julgada já consumada, como também lhe é vedada sua supressão total, mesmo com eficácia apenas futura. Por derradeiro, na perspectiva constitucional, só é concebível falar em coisa julgada de sentença definitiva prolatada em cognição exauriente. À luz do devido processo legal (art. $5^{\circ}, \mathrm{XXXV}$, da CF), a cristalização de situações jurídicas demanda prévia oitiva das partes, amplo debate sobre a lide e adequada instrução probatória, com o exaurimento da atividade jurisdicional. ${ }^{52}$

\section{Bibliografia}

ALEXY, Robert. Direito constitucional e direito ordinário. Jursidição constitucional e jurisdição especializada. Trad. L. A. Heck. São Paulo: RT, 2003.

AROCA, Juan Montero e MATÍES, José Flors. Amparo constitucional y proceso civil, Valência: Tirant lo blanch, 2008.

ASSIS, Araken de. Eficácia da coisa julgada inconstitucional. Revista Jurídica, n. 301, nov. 2002.

ATALIBA, Geraldo. República e Constituição. 3. ed. atual. Rosolea Miranda Folgosi. São Paulo: Malheiros, 2011.

BARROSO, Luís Roberto. Interpretação e aplicação da Constituição: fundamentos de uma dogmática constitucional transformadora. São Paulo: Saraiva, 1996.

BARROSO, Luís Roberto. Em algum lugar do passado: segurança jurídica, direito intertemporal e o novo Código Civil. Revista de direito RENOVAR, v. 21, 2005.

das partes quando buscam a tutela jurisdicional (inciso III), a própria coisa julgada antecedente (inciso IV), a ofensa à ordem jurídica (inciso V) ou ainda a manifesta contrariedade aos fatos ou a prova (incisos Vi a IX).

${ }^{52} \mathrm{O}$ "parâmetro fundamental para a atribuição da coisa julgada é a presença de cognição exauriente. $\mathrm{O}$ instituto - que tem por essência a imutabilidade - é constitucionalmente incompatível com decisão proferida com base em cognição superficial e, por isso mesmo, provisória, sujeita à confirmação. Há uma vinculação constitucional da coisa julgada à cognição exauriente. Ainda que não exista disposição expressa nesse sentido, isso é uma imposição da proporcionalidade e da razoabilidade extraíveis inclusive da cláusula do devido processo legal" (TALAMINI, Eduardo. Coisa julgada e sua revisão. São Paulo: RT, 2005, p. 53). 
BARROSO, Luís Roberto. O controle de constitucionalidade no direito brasileiro: exposição sistemática da doutrina e análise crítica da jurisprudência. São Paulo: Saraiva, 2004.

BIAVATI, Paolo; CARPI, Federico. Diritto procesuale comunitário. 2. ed. Milano: Giufrè, 2000.

BUENO, Cassio Scarpinella. "Coisa julgada inconstitucional": uma homenagem a Araken de Assis. In: ALVIM, Arruda; ALVIM, Eduardo Arruda; BRUSCHI, Gilberto Gomes; CHECHI, Mara Larsen; COUTO, Mônica Boneti. Execução civil e temas afins do CPC/1973 ao Novo CPC: estudos em homenagem ao professor Araken de Assis. São Paulo: RT, 2014.

BUZAID, Alfredo. Da ação direta de inconstitucionalidade no direito brasileiro. São Paulo: Saraiva, 1958.

CARRAZZA, Roque Antonio. Curso de direito constitucional tributário. 6. ed. São Paulo: Malheiros, 1994.

DIDIER JÚNIOR, Fredie; BRAGA, Paula Sarno; OLIVEIRA, Rafael. Curso de direito processual civil. 4. ed. Salvador: Juspodium, 2009, v. 2.

DIMOULIS, Dimitri; Martins, Leonardo. Teoria geral dos direitos fundamentais. São Paulo: RT, 2007.

DINAMARCO, Cândido Rangel. Fundamentos do processo civil moderno. 6. ed. São Paulo: Malheiros, 2010, v. 1.

DINAMARCO, Cândido Rangel. Nova era do processo civil. 4. ed. São Paulo: Malheiros, 2013.

DINIZ, Maria Helena. Lei de introdução às normas do direito brasileiro interpretada. 18. ed. São Paulo: Saraiva, 2013.

FERNANDES, Sérgio Ricardo de Arruda. Alguns aspectos da coisa julgada material no direito processual civil brasileiro. RePro 62. São Paulo: RT, abr/jun. 1991.

GRAU, Eros Roberto. $O$ direito posto e o direito pressuposto. 7. ed. São Paulo: Malheiros, 2008.

GRECO, Leonardo. Eficácia da Declaração 'Erga Omnes' de Constitucionalidade ou Inconstitucionalidade em Relação à Coisa Julgada Anterior. In: "Relativização da Coisa Julgada", p. 251, 2. ed. 2008. Salvador: JusPODIVM.

GRECO FILHO, Vicente. Direito processual civil brasileiro. 19. ed. São Paulo: Saraiva, 2008, v. 2.

GRINOVER, Ada Pellegrini. O processo: estudos e pareceres. 2. ed. São Paulo: DPJ Editora, 2009. 
KELSEN, Hans. Teoria pura do direito. 6. ed. trad. João Baptista Machado. São Paulo: Martins Fontes, 2003.

LIMA, Paulo Roberto de Oliveira. Contribuição à teoria da coisa julgada. São Paulo: Editora Revista dos Tribunais, 1997.

MARINONI, Luiz Guilherme. Coisa julgada inconstitucional. 2. ed. São Paulo: RT, 2010.

MIRANDA, Jorge. Manual de direito constitucional: inconstitucionalidade e garantia da constituição. 2. ed. Coimbra: Coimbra Editora, 2005, t. 6.

MIRANDA, Pontes de. Comentários à Constituição de 1967. São Paulo: RT, 1968.

NASCIMENTO, Carlos Valder do; PEREIRA JÚNIOR, Lourival. Natureza da coisa julgada: uma abordagem filosófica. In: NASCIMENTO, Carlos Valder do; DELGADO, José Augusto (Coord). Coisa julgada inconstitucional. 2. ed. Belo Horizonte: Fórum, 2008.

NERY JUNIOR, Nelson. Princípios do processo civil na Constituição Federal. 10. ed. São Paulo: RT, 2010.

OTERO, Paulo. Ensaio sobre o caso julgado inconstitucional. Lisboa: Lex Edições Jurídicas, 1993.

PORTO, Sérgio Gilberto. Coisa julgada civil. 3. ed. São Paulo: RT, 2006, p. 59-60.

RADBRUCH, Gustav. Filosofia do Direito. 6. ed. Coimbra: Ed. Coimbra, 1997.

RÁO, Vicente. O direito e a vida dos direitos. 3. ed. atual. Ovídio Rocha Barros Sandoval. São

Paulo: RT, 1991, v. 1.

RINCÓN, Jorge Carreras del. Comentarios a la doctrina procesal civil del tribunal constitucional y del tribunal supremo, Madrid: Marcial Pons, 2002, p. 411; JUNOY, Joan Picó y. Las garantias constitucionales del proceso, Barcelona: J. M. Bosch Editor, 1997.

RODRIGUES JÚNIOR, Otávio Luiz. Coisa julgada e Constituição: os efeitos da lei nova, da mudança de interpretação dos tribunais e das emendas constitucionais sobre a coisa julgada. Revista do Curso de Mestrado de Direito da UFC, Fortaleza, v. 16/18, n. 4/6, p. 87, jan./dez. 1997-1999.

ROSENBERG, Leo; SCHWAB, Karl H.; GOTTWALD, Peter. Zivilprofsrecht. 15. ed. Munique: Beck, 1993.

SILVA, José Afonso da. Curso de direito constitucional positivo. 29. ed. São Paulo: Malheiros, 2007.

TALAMINI, Eduardo. Coisa julgada e sua revisão. São Paulo: Revista dos Tribunais,

http://revistasapereaude.org/index.php/edicoes/ano-5-volume-4-novembro-2016 
2005. 
THEODORO JÚNIOR, Humberto; FARIA, Juliana Cordeiro de. Reflexões sobre o princípio da intangibilidade da coisa julgada e sua relativização. In: NASCIMENTO, Carlos Valder do; DELGADO, José Augusto (Coord). Coisa julgada inconstitucional.2. ed. Belo Horizonte: Fórum, 2008.

THEODORO JÚNIOR, Humberto; FARIA, Juliana Cordeiro de. Reflexões sobre a coisa julgada inconstitucional $e$ os instrumentos processuais para seu controle. In: NASCIMENTO, Carlos Valder do; THEODORO JÚNIOR, Humberto; FARIA, Juliana Cordeiro de. Coisa julgada inconstitucional: a questão da segurança jurídica. Belo Horizonte: Fórum, 2011.

WAMBIER, Teresa Alvim Arruda Alvim; MEDINA, José Miguel Garcia. O dogma da coisa julgada. São Paulo: RT, 2003. 